\title{
Aos leitores
}

DOI: $10.1590 / 1809-584420152 \mid$

É com grande alegria e satisfação que apresentamos a nova edição da INTERCOM - REVISTA BRASILEIRA DE CIENNCIAS DA COMUNICAÇÃO - RBCC. Como sempre, nos esforçamos para reunir, a cada número, variedade e atualidade temática, o que acreditamos possibilitar um intenso intercâmbio com pesquisadores e estudiosos da Comunicação de diversas gerações do Brasil e de algumas partes do mundo. Além disso, cada volume costuma oferecer uma noção - ainda que seja de uma reduzida parte do crescente universo comunicacional do que vem sendo produzido não só em termos de pesquisa acadêmica sobre as diversas, ricas e, às vezes, contraditórias, situações dos meios de Comunicação na Europa e no Brasil.

Esta edição conta com 13 artigos. Neles podemos encontrar aspectos teóricos e discursivos da Comunicação - como, por exemplo, nos estudos Construcción de la realidad, comunicación y vida cotidiana. Una aproximación a la obra de Thomas Luckmann; A multiplicidade de vozes no discurso jornalístico: estudo da polifonia no jornalismo à luz de uma perspectiva modular da organização do discurso; e Informação Jornalística: da mediação à midiatização - e práticas culturais e comunitárias, como em: Comunicação, economia criativa e desenvolvimento local: a experiência do 'Núcleo de Comunicação Bombando Cidadania'; Escuchando música en el transporte público. Sobre usos de la telefonía móvil por parte de jóvenes; e O subúrbio feliz do pagode carioca.

Há também os artigos que propiciam uma discussão específica sobre a relação meios de comunicação e meio ambiente, saúde e tecnologia, revelando uma preocupação de âmbito interdisciplinar da Comunicação: o desenvolvimento da ciência como um todo. É o caso das pesquisas: A cobertura de ciência em três jornais paraenses: um estudo longitudinal; Jornalismo e meio ambiente: apontamentos sobre dez anos de produção acadêmica nos eventos da Intercom; Afetar e ser afetado pelo acontecimento: coberturas jornalísticas da Aids e impactos sociais; e 
'SoftPower' y Televisión Digital en Sudamérica: la campaña brasileña de promoción del ISDB-Tb según los relatos de sus realizadores.

Outros artigos privilegiam as correlações entre imagem e técnica, como: A fotografia como catalisador simbólico. Notas para uma hermenêutica da fantástica em imagens técnicas; e O testemunho na TV: 'Profissão Repórter' e a encenação da encenação. Em todos eles chamamos a atenção para os aspectos metodológicos, bem como o embasamento teórico. Entre outros pontos, as questões teóricas e metodológicas garantem reflexões aprofundadas e o consequente fortalecimento e consolidação do campo da Comunicação.

Destaque ainda para a seção Arena, com uma reflexão sobre os quase 50 anos do livro História da imprensa no Brasil, de Nelson Wernek Sodré - considerado um marco para se pensar os estudos de história da Comunicação no Brasil.

A entrevista desta edição da RBCC é uma verdadeira aula de Jornalismo esportivo. Unindo prática profissional e acadêmica, o professor Antônio Alcoba Lopez, da Universidad Complutense de Madrid, conta sua trajetória de vida e faz importantes análises do cenário esportivo midiático mundial. Outro destaque é a seção especial Memória, que incluímos para registrar um texto do professor José Marques de Melo, feito a partir de fragmentos de memória do jornalista, acadêmico e anistiado político. Por fim, as resenhas mostram alguns dos principais lançamentos bibliográficos da área.

Registramos que este número - como os três anteriores - publica na sua versão digital (http://www.portcom.intercom.org.br/revistas/ index.php/revistaintercom/issue/current) todos os artigos traduzidos para o inglês. É uma forma de oferecer uma possibilidade maior de acessibilidade internacional e assim contribuir para difundir a produção em Comunicação de brasileiros e estrangeiros que publicam artigos na RBCC.

Desejando boa e produtiva leitura a todos, aproveitamos para agradecer aos autores, avaliadores pareceristas e colaboradores desta edição - afinal, trata-se de um trabalho de equipe, no qual o esforço e participação de cada um durante todo o processo de edição da RBCC é imprescindível para o resultado final.

Cicilia M.Krohling Peruzzo (Universidade Metodista de São Paulo, Faculdade de Comunicação, Programa de Pós-Graduação em Comunicação Social. São Bernardo do Campo, SP, Brasil) 